Edukatif : Jurnal Ilmu Pendidikan Volume 4 Nomor 1 Tahun 2022 Halm 1094 - 1110

EDUKATIF: JURNAL ILMU PENDIDIKAN

Research \& Learning in Education

https:/ledukatif.org/index.php/edukatif/index

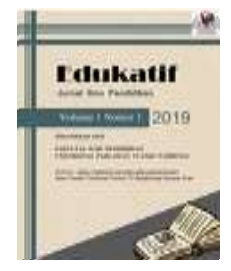

\title{
Analisis Pengelolaan Koperasi Sekolah Melalui Rasio Laporan Keuangan di Sekolah Menengah Atas
}

\author{
Belin Puspa Sari $^{1 凶}$, Zahruddin Hodsay ${ }^{2}$, Hendri Gunawan ${ }^{3}$ \\ Universitas PGRI Palembang, Indonesia ${ }^{1,2,3}$ \\ E-mail : $\underline{\text { belinpuspasari385@ gmail.com }}^{1}$, $\underline{\text { zhodsay@ gmail.com }}^{2}$, jayasampurna@ gmail.com ${ }^{3}$
}

\begin{abstract}
Abstrak
Koperasi SMA Negeri 4 Palembang yang semestinya diperuntukkan bagi warga sekolah (guru, staf organisasi, siswa) namun dalam pelaksanaannya hanya melibatkan guru dan staf organisasi sekolah, serta pengurus dan anggota sejauh ini tidak mengetahui tingkat efisiensi dari pengelolaan koperasi apakah koperasi tersebut dalam kategori sehat atau tidak sehat. Penelitian ini bertujuan untuk mengetahui pengelolaan koperasi sekolah ditinjau dari rasio permodalan, rasio efisiensi, serta rasio kemandirian dan pertumbuhan dari laporan keuangan tahun 2018-2020. Metode penelitian yang digunakan metode kualitatif. Hasil penelitian menunjukkan bahwa: (1) permodalan untuk rasio modal sendiri terhadap total asset dan rasio kecukupan modal sendiri pada Koperasi Sehati SMA Negeri 4 Palembang tahun 2018-2020 dalam predikat sehat; (2) efisiensi untuk rasio beban operasi anggota terhadap partisipasi bruto dan rasio efisiensi pelayanan dalam predikat sehat; dan (3) kemandirian dan pertumbuhan untuk rasio rentabilitas asset, rasio rentabilitas modal sendiri dan rasio kemandirian operasional dalam kondisi sehat.
\end{abstract}

Kata Kunci: Pengelolaan, Koperasi Sekolah, Rasio Laporan Keuangan

\section{Abstract}

The SMA Negeri 4 Palembang Cooperative should be intended for school residents (teachers, organizational staff, students) but in its implementation only involves teachers and school organizational staff, as well as administrators and members so far, do not know the level of efficiency of cooperative management whether the cooperative is in the healthy category not or not healthy. The purpose of this study was to determine the management of school cooperatives in terms of the capital ratio, efficiency ratio, as well as independence and growth ratio of the 2018-2020 financial statements. The research method used is qualitative. The results of the study show that: (1) the capital for the ratio of equity to total assets and the ratio of own capital adequacy at the Sehati Cooperative SMA Negeri 4 Palembang in 2018-2020 is in a healthy predicate; (2) efficiency for the ratio of operating expenses of members to gross participation and the ratio of service efficiency in a healthy predicate; and (3) independence and growth for asset profitability ratios, equity profitability ratios and operational independence ratios in healthy conditions.

Keywords: management, school cooperative, financial statement ratio

Copyright (c) 2022 Belin Puspa Sari, Zahruddin Hodsay, Hendri Gunawan

$\triangle$ Corresponding author:

Email : belinpuspasari385@gmail.com

DOI : https://doi.org/10.31004/edukatif.v4i1.1993

ISSN 2656-8063 (Media Cetak)

ISSN 2656-8071 (Media Online)

Edukatif : Jurnal Ilmu Pendidikan Vol 4 No 1 Tahun 2022 p-ISSN 2656-8063 e-ISSN 2656-8071 
1095 Analisis Pengelolaan Koperasi Sekolah Melalui Rasio Laporan Keuangan di Sekolah Menengah Atas Belin Puspa Sari, Zahruddin Hodsay, Hendri Gunawan

DOI: https://doi.org/10.31004/edukatif.v4i1.1993

\section{PENDAHULUAN}

Perekonomian rakyat merupakan sistem yang sifatnya liat atau kenyal, tahan banting, dan tangguh terhadap benturan krisis. Akan tetapi, kehadirannya tidak pernah mendapatkan perhatian secara sungguhsungguh. Padahal sifat ekonomi kerakyatan tersebut, apabila benar-benar diperhatikan, dapat menjadi soko guru atau tiang penyanggah ekonomi Indonesia untuk semakin baik. Oleh karenanya, perlu ada lembaga yang dapat mengakomodasi pihak yang membutuhkan dana dan pihak yang memiliki dana. Dana atau modal inilah yang digunakan untuk menggiatkan sektor riil atau ekonomi rakyat (Santoso, 2021).

Koperasi merupakan salah satu bentuk badan hukum yang sudah lama dikenal di Indonesia. Pelopor pengembangan perkoperasian di Indonesia adalah Bung Hatta, dan sampai saat ini beliau sangat dikenal sebagai bapak koperasi Indonesia. Sampai saat ini koperasi menempati kedudukan yang sangat terhormat dalam perekonomian Indonesia. Hal itu tidak hanya tampak pada ketegasan sikap dalam Undang-Undang Dasar tahun 1945 pada pasal 33 ayat (1) yang berbunyi "Perekonomian disusun sebagai usaha bersama berdasar atas asas kekeluargaan". Makna yang terkandung dalam ayat tersebut sangat dalam yakni sistem ekonomi yang dikembangkan seharusnya tidak basis persaingan serta atas asas yang sangat individualistik (Undang-Undang Dasar Tahun 1945 Pasal 33, n.d.).

Perkoperasian di Indonesia terkandung dalam Undang-Undang RI Nomor 17 Tahun 2012 tentang Perkoperasian Pasal 1 ayat (1), mengemukakan pengertian koperasi adalah "badan hukum yang didirikan oleh orang perseorangan atau badan hukum koperasi, dengan pemisahan kekayaan para anggota sebagai modal untuk menjalankan usaha, yang memenuhi aspirasi dan kebutuhan bersama dibidang ekonomi, sosial, dan budaya" (Undang-Undang RI Nomor 17 Tahun 2012 Tentang Perkoperasian Pasal 1, n.d.).

Selama perjalanannya koperasi yang sebenarnya sangat sesuai dengan jiwa bangsa Indonesia justru perkembangnnya tidak menggembirakan. Koperasi yang dianggap sebagai anak kandung dan tulang punggung ekonomi kerakyatan justru hidupnya pasang surut, sekalipun pemerintah telah berjuang keras untuk menghidupkan dan memberdayakan koperasi di tengah-tengah masyarakat. Begitu banyak kemudahan yang diperoleh oleh badan hukum koperasi melalui berbagai fasilitas, namun tidak banyak mengubah kehidupan koperasi itu sendiri. Koperasi dikenalkan di Indonesia oleh R. Aria Wiriatmadja di Purwokerto, Jawa Tengah pada tahun 1986. Pergerakan koperasi di Indonesia mengadakan kongres koperasi yang pertama di Tasikmalaya. Pada tanggal 12 Juni 1947 kemudian ditetapkan sebagai hari koperasi Indonesia. Sejak tahun 1975 telah dikeluarkan keputusan oleh Menteri Perdagangan dan koperasi serta Menteri Pendidikan dan Kebudayaan nomor 719/Kbp/XII/79 dan nomor 282a/P/1979 tentang Pendirian perkoperasian sekolah, universitas dan lain-lain lembaga pendidikan di lingkungan Depdikbud.

Koperasi sekolah adalah koperasi yang anggotanya terdiri dari siswa-siswa Sekolah Dasar (SD), Sekolah Menengah Pertama (SMP), Sekolah Menengah Atas (SMA), pondok pesantren dan lembaga pendidikan lainnya yang setaraf dan mempunyai tujuan untuk menunjang pendidikan yang dilakukan di dalam kelas dengan berbagai tindakan praktek yang berhubungan dengan kegiatan koperasi. Hal ini selaras dengan pendapat (Sukmayadi, 2020) bahwa, koperasi sekolah beranggotakan siswa-siswi di lingkungan sekolah. Koperasi ini didirikan pada berbagi tingkatan sesuai jenjang pendidikan. Misalnya koperasi sekolah dasar, koperasi sekolah menengah pertama, koperasi sekolah menengah atas, dan koperasi mahasiswa (KopMa). Koperasi sekolah didirikan berdasarkan Surat Keputusan Menteri Tenaga Kerja, Transmigrasi, dan Koperasi no. 638/SKPT/Men/1974, tentang Ketentuan Pokok Pendirian Koperasi Sekolah.

Koperasi sebagai organisasi ekonomi dalam mencapai keberhasilannya tidak hanya dapat dilihat dari konteks lembaga yang secara kuantitatif telah menunjukan perkembangan tertentu, akan tetapi juga harus dilihat dari konteks koperasi sebagai badan usaha yang berusaha mengkombinasi sumber dayanya secara optimal (Bangsawan, 2016). Koperasi sebagai badan usaha yang perlu dikelola dengan cara profesional, sehingga dapat menjalankan usahanya dengan baik dalam rangka meningkatkan kesejahteraan warga sekolah. 
1096 Analisis Pengelolaan Koperasi Sekolah Melalui Rasio Laporan Keuangan di Sekolah Menengah Atas Belin Puspa Sari, Zahruddin Hodsay, Hendri Gunawan

DOI: https://doi.org/10.31004/edukatif.v4i1.1993

Koperasi merupakan badan usaha yang mengorganisasikan pemanfaatan dan menggunakan sumber daya ekonomi para anggotanya atas dasar prinsip-prinsip koperasi dan manfaat usaha ekonominya untuk meningkatkan taraf hidup anggotanya pada khususnya dan warga sekolah pada umumnya. Prinsip-prinsip koperasi terdiri dari kemandirian, keanggotaan bersifat sukarela dan terbuka, pengelolaan dilakukan dengan demokratis, pembagian sisa hasil usaha (SHU) dilakukan secara adil sebanding dengan besarnya jasa. Koperasi juga merupakan salah satu badan usaha yang bergerak di bidang keuangan. Oleh karena itu, sebagai badan usaha keuangan maka koperasi harus dapat meningkatkan kinerjanya dalam menghasilkan pendapatan.

Pembentukan koperasi di sekolah pada dasar sasarannya adalah untuk melatih dan mendidik siswa agar lebih bertanggung jawab, dan memiliki keterampilan dalam berkoperasi agar nantinya berguna di masyarakat. Namun muncul fenomena dimana pembentukan koperasi di sekolah bukan bertujuan untuk melatih dan mendidik siswa sebagaimana fungsinya, melainkan untuk membantu ekonomi guru dan pegawai sekolah, hal ini dikarenakan siswa tidak diikutsertakan sebagai anggotanya dan unit usahanya pun koperasi simpan pinjam dan penjualan alat kelengkapan sekolah seperti buku, alat tulis dan lainnya.

Kecenderungan fenomena tersebut juga terjadi pada Sekolah Menengah Atas (SMA) Negeri 4 Palembang, koperasi yang semestinya diperuntukkan bagi warga sekolah (guru, staf organisasi, siswa) namun dalam pelaksanaannya hanya melibatkan guru dan staf organisasi sekolah, sehinga tujuan didirikannya koperasi untuk melatih dan mendidik siswa sebagaimana fungsinya tidak dapat terwujud, serta menyebabkan rendahnya kemampuan berpikir kritis siswa dalam berorganisasi. Berpikir kritis menurut Desmita dikutip (Cahyani, 2021) adalah kemampuan berpikir secara logis, reflektif, dan produktif yang diaplikasikan dalam menilai situasi untuk membuat pertimbangnya dan keputusan yang baik. Hal ini juga selaras pendapat Pratiwi dikutip (Apriati, 2021) perkembangan wawasan pada diri siswa, penyaluran energi positif seperti dapat menyalurkan emosional yang terpendam, dorongan komunikasi, rangsangan untuk kreatif, dan anak dapat belajar bermasyarakat dengan teman serta lingkungan sekitarnya tidak terpenuhi. Oleh karena guru dan staf organisasi sekolah hendaknya melibatkan siswa menjadi anggota dalam kepengurusan koperasi sekolah sehingga dapat meningkatkan kemampuan berfikirnya. Permasalahan ini juga tidak sejalan dengan pendapat (Sukidjo, 2016) bahwa, keberadaan koperasi sekolah dapat digunakan sebagai wahana pembelajaran berkoperasi dan berusaha untuk mengasah dan mengembangkan potensi kewirausahaansehingga nantinya mereka memiliki alternatif menjadi wirausaha mandiri atau sebagai pencari kerja. Selain masalah peruntukan pengelolaan koperasi, di SMA Negeri 4 Palembang juga ditemukan pada laporan keuangan sehingga diketahui tingkat efisiensi dari pengelolaan koperasi apakah koperasi tersebut dalam kategori sehat atau tidak sehat. Tingkat kesehatan koperasi SMA Negeri 4 Palembang dapat dilihat dari laporan keuangan pada periode 20182020 seperti tabel berikut:

Tabel 1

Pengelolaan Laporan Keuangan Koperasi SMA Negeri 4 Palembang Periode 2018-2020

\begin{tabular}{|c|c|c|c|c|}
\hline \multirow{2}{*}{ No } & \multirow{2}{*}{ Keuangan } & \multicolumn{3}{|c|}{ Tahun } \\
\hline & & 2018 & 2019 & 2020 \\
\hline 1 & Modal s & Rp49.965.000 & Rp72.005.000 & Rp43.600.000 \\
\hline 2 & Total as & $\operatorname{Rp} 110.175 .400$ & Rp138.790.500 & Rp88.794.000 \\
\hline 3 & SHU y: & Rp8.010.400 & Rp25.576.500 & $\mathrm{Rp} 5$ \\
\hline 4 & SHU & & 30.090 .000 & 00 \\
\hline 5 & Kas & Rp6 & $\operatorname{Rp} 87.550 .000$ & Rp70. \\
\hline 6 & Beba & 000 & Rp1.030.000 & Rp680.000 \\
\hline 7 & Partisipasi b & Rp. 9424.000 & Rp30.090.000 & Rp3.340.000 \\
\hline 8 & Partisipasi netto & Rp8.010.400 & Rp25.576.500 & Rp5.389.000 \\
\hline 9 & Volume pinjaman & Rp20.721.000 & Rp14.800.000 & Rp15.500.000 \\
\hline
\end{tabular}

(Sumber: Laporan Keuangan Koperasi Sehati SMA Negeri 4 Palembang tahun 2018-2020) 
1097 Analisis Pengelolaan Koperasi Sekolah Melalui Rasio Laporan Keuangan di Sekolah Menengah Atas Belin Puspa Sari, Zahruddin Hodsay, Hendri Gunawan

DOI: https://doi.org/10.31004/edukatif.v4i1.1993

Tabel di atas menunjukkan bahwa modal sendiri, total asset, SHU yang dibagikan, SHU kotor, kas, beban operasi anggota, partipasi bruto, partisipasi netto, dan volume penjualan pada periode 2018-2020 mengalami fluktuasi, serta menunjukkan nilai tertinggi pada tahun 2019 dibandingkan pada tahun 2018 dan 2020. Oleh karena itu, peneliti merasa perlu untuk melakukan penelitian terhadap pengelolaan koperasi sekolah di Sekolah Menengah Atas (SMA) Negeri 4 Palembang. Berdasarkan permasalahan tersebut, maka penulis bertujuan untuk mengetahui pengelolaan koperasi sekolah melalui rasio laporan keuangan yang meliputi: analisis rasio permodalan koperasi, rasio efisiensi, dan rasio kemandirian dan pertumbuhan dari laporan keuangan tahun 2018-2020.

Koperasi sekolah di SMA Negeri 4 Palembang merupakan jenis koperasi simpan pinjam, yaitu yang bergerak dalam pengumpulan simpanan dari para anggotanya untuk dipinjamkan kembali kepada anggotanya yang membutuhkan bantuan modal untuk usahanya. Serta koperasi konsumsi, yaitu menyediakan barangbarang yang akan dijual, seperti alat tulis, buku pelajaran, pakaian seragam dan berbagai jenis minuman dan makanan ringan. Selain itu juga, koperasi dalam operasionalnya tidak terlepas dari pembukuan secara akuntansi yang disajikan dalam laporan keuangan. Menurut (Harahap, 2015), laporan keuangan merupakan ouput dan hasil akhir dari proses akuntansi. Laporan keuangan inilah yang menjadi bahan informasi bagi para pemakainya sebagai salah satu bahan dalam proses pengambilan keputusan. Sedangkan menurut (Fahmi, 2015), laporan keuangan dianalisis untuk melihat sejauh mana suatu koperasi telah melaksanakan dengan menggunakan aturan-aturan pelaksanaan keuangan secara baik dan benar. Di samping sebagai informasi, laporan keuangan juga sebagai pertanggungjawaban atau accountability. Sekaligus menggambarkan indikator kesuksesan suatu koperasi dalam mencapai tujuannya.

Menurut Peraturan Deputi Bidang Pengawasan Kementrian Koperasi dan Usaha Kecil dan Menengah No.06/Per/Dep.6/2016 tentang pedoman penilaian kesehatan koperasi simpan pinjam dan unit simpan pinjam koperasi analisis rasio untuk unit koperasi terbagi menjadi rasio permodalan, rasio kualitas aktiva produktif, rasio efisiensi, rasio likuiditas, rasio kemandirian dan pertumbuhan, dan jati diri koperasi (Peraturan Deputi Bidang Pengawasan Kementerian Koperasi Dan Usaha Kecil Dan Menengah No.06/Per/Dep.6/2016 Tentang Pedoman Penilaian Kesehatan Koperasi Simpan Pinjam Dan Unit Simpan Pinjam, n.d.).

Penelitian yang serupa telah dilakukan (Hodsasy, 2019) membahas mengenai penilaian kesehatan keuangan koperasi simpan pinjam. Novelty (kebaruan) studi ini adalah koperasi yang diteliti beranggotakan seluruh staff, dewan guru serta karyawan yang berada di SMK Muhammadiyah 2 Palembang. Selama ini belum pernah melakukan penilaian kesehatan keuangan. Objek yang diteliti laporan keuangan tahun 2015 sampai 2017. Penilaian Koperasi Simpan Pinjam dapat dinilai berdasarkan Peraturan Pengawasan Kementerian Koperasi Dan Usaha Kecil Menengah (UKM) Republik Indonesia Peraturan Nomor: 06/Per/Dep.6/IV/2016 tentang kriteria standar penilaian Kesehatan Koperasi Simpan Pinjam dan Unit Simpan Pinjam. Penelitian ini menemukan bahwa tingkat koperasi dalam kategori pengawasan.

Penelitian lainnya dilakukan (Larasati, 2021) mengenai kesehatan keuangan koperasi. Kebaruan penelitian diantaranya koperasi ini didirikan dengan bekerja sama dengan perusahaan agar hasil panen kelapa sawit para petani dapat tersalurkan dengan baik, selain itu dengan adanya KUD ini petani tidak mengalami kesulitan dalam mendapatkan alat-alat pertanian dan juga simpan pinjam. Objek penelitian ini laporan keuangan tahun 2015 sampai 2018. Temuan penelitian ini adalah KUD dalam kategori cukup sehat.

Perbedaan dengan penelitian sebelumnya, pada penelitian ini peneliti menganalisis laporan keuangan 2018 sampai 2020, dan rasio permodalan (rasio modal sendiri terhadap total asset dan kecukupan modal sendiri), rasio efisiensi (beban operasi anggota terhadap partisipasi bruto, dan efisiensi pelayanan), serta rasio kemandirian dan pertumbuhan (rasio rentabilitas asset, rasio rentabilitas modal sendiri dan rasio kemandirian operasional). Dipilihnya tahun 2018-2020 dan analisis rasio tersebut dikarenakan sesuai dengan kondisi laporan keuangan koperasi, serta memberikan gambaran kepada pengurus dan anggota koperasi terhadap tingkat kesehatan koperasi yang selama ini belum pernah diketahui apakah dalam kategori sehat, cukup, 
1098 Analisis Pengelolaan Koperasi Sekolah Melalui Rasio Laporan Keuangan di Sekolah Menengah Atas Belin Puspa Sari, Zahruddin Hodsay, Hendri Gunawan

DOI: https://doi.org/10.31004/edukatif.v4i1.1993

kurang, tidak sehat atau tidak sehat. Dengan mengetahui gambaran tingkat kesehatan koperasi, maka pengurus dan anggota dapat merumuskan kebijakan untuk pengembangan usaha dan mewujudkan koperasi yang efektif, efisien, serta terciptanya pelayanan yang memuaskan pada warga sekolah.

\section{METODE PENELITIAN}

Rancangan penelitian ini menggunakan rancangan deskriptif kualitatif. Menurut Sugiyono (2019: 25), deskriptif kualitatif adalah penelitian yang berlandaskan pada filsafat postpositivisme atau enterpretif, digunakan untuk meneliti pada kondisi objek yang alamiah, di mana peneliti adalah sebagai instrumen kunci, teknik pengumpulan data dilakukan secara trianggulasi (Sugiyono, 2019).

Pada penelitian kualitatif yang menjadi subjek penelitian ini adalah koperasi SMA Negeri 4 Palembang. Untuk memperoleh data, penulis menggunakan metode dokumentasi berupa laporan keuangan koperasi periode 2018-2020. Data yang diperoleh dianalisis merujuk Peraturan Deputi Bidang Pengawasan Kementrian Koperasi dan Usaha Kecil dan Menengah No.06/Per/Dep.6/2016, yang terdiri dari rasio permodalan, rasio efisiensi, serta rasio kemandirian dan pertumbuhan. Jelasnya rasio tersebut diuraikan berikut ini.

1. Rasio permodalan

a. Rasio modal sendiri terhadap total aset

$$
=\frac{\text { Modal Sendiri }}{\text { Total Aset }} \times 100 \%
$$

b. Rasio modal sendiri terhadap pinjaman diberikan yang beresiko

$$
=\frac{\text { ModalSendiri }}{\text { Pinjaman Diberikan yang Beresiko }} \times 100 \%
$$

c. Rasio kecukupan modal sendiri

$$
=\frac{\text { Modal Sendiri Tertimbang }}{\text { ATMR }} \times 100 \%
$$

2. Rasio Efisiensi

a. Rasio beban operasi anggota terhadap partisipasi bruto

$$
=\frac{\text { Beban Operasi Anggota }}{\text { Partisipasi Bruto }} \times 100 \%
$$

b. Rasio beban usaha terhadap SHU kotor

$$
=\frac{\text { Beban Usaha }}{\text { SHU Kotor }} \times 100 \%
$$

c. Rasio efisiensi pelayanan

$$
=\frac{\text { Biaya Karyawan }}{\text { Volume Penjualan }} \times 100 \%
$$

3. Rasio Kemandirian dan Pertumbuhan

a. Rentabilitas aset

$$
=\frac{\text { SHU Sebelum Pajak }}{\text { Total Aset }} \times 100 \%
$$

b. Rentabilitas modal sendiri 
1099 Analisis Pengelolaan Koperasi Sekolah Melalui Rasio Laporan Keuangan di Sekolah Menengah Atas Belin Puspa Sari, Zahruddin Hodsay, Hendri Gunawan

DOI: https://doi.org/10.31004/edukatif.v4i1.1993

$$
=\frac{\text { SHU Bagian Anggota }}{\text { Total Modal Sendiri }} \times 100 \%
$$

c. Kemandirian operasional pelayanan

$$
=\frac{\text { Partisipasi Neto }}{\text { Beban Usaha }+ \text { Beban Perkoperasian }} \times 100 \%
$$

\section{HASIL DAN PEMBAHASAN}

Analisis penelitian berpedoman pada peraturan Menteri Koperasi dan UKM No. 06/Per/Dep.6/IV/2016. Aspek yang dinilai yaitu Permodalan, Kualitas Aktiva Produktif, dan Efisiensi. Hasil analisis aka memberikan gambaran mengenai tingkat kesehatan keuangan pada Koperasi Sekolah di SMA Negeri 4 Palembang. Adapun perhitungan rasio masing-masing aspek penilaian kesehatan koperasi akan diuraikan sebagai berikut:

Permodalan sendiri koperasi merupakan modal yang menanggung resiko atau disebut dengan modal ekuiti. Analisis permodalan terdiri dari: rasio modal sendiri terhadap total asset, rasio modal sendiri terhadap pinjaman diberikan yang berisiko dan rasio kecukupan modal sendiri. Dari ke-3 rasio permodalan tersebut, yang dapat dianalisis adalah rasio modal sendiri terhadap total asset dan rasio kecukupan modal sendiri, dikarenakan pada Koperasi Sehati SMA Negeri 4 Palembang tidak terdapat risiko yang ditanggung koperasi, karena pembayaran pinjaman langsung dipotong melalui gaji. Modal sendiri dapat berasal dari simpanan pokok, simpanan wajib dan dana cadangan.

1. Rasio modal sendiri terhadap total asset

a. Tahun 2018

$$
\begin{aligned}
& =\frac{49.965 .000}{110.175 .400} \times 100 \% \\
& =45,35 \%
\end{aligned}
$$

b. Tahun 2019

$$
\begin{aligned}
& =\frac{72.005 .000}{138.790 .500} \times 100 \% \\
& =51,88 \%
\end{aligned}
$$

c. Tahun 2020

$$
\begin{aligned}
& =\frac{43.600 .000}{88.794 .000} \times 100 \% \\
& =49,10 \%
\end{aligned}
$$

Hasil perhitungan rasio modal sendiri Koperasi Sekolah di SMA Negeri 4 Palembang dapat dilihat pada tabel berikut.

Tabel 2

Rasio \begin{tabular}{cccc} 
Modal Sendiri terhadap Total Asset Tahun 2018-2020 \\
\cline { 2 - 5 } Tahun & Modal Sendiri & Total Assets & Rasio \\
\hline 2018 & 49.965 .000 & 110.175 .400 & $45,35 \%$ \\
\hline 2019 & 72.005 .000 & 138.790 .500 & $51,88 \%$ \\
\hline 2020 & 43.600 .000 & 88.794 .000 & $49,10 \%$ \\
\hline
\end{tabular}

Tabel di atas, selanjutnya diintepretasikan pada standar perhitungan rasio modal sendiri terhadap total asset pada tabel berikut.

\section{Tabel 3}


1100 Analisis Pengelolaan Koperasi Sekolah Melalui Rasio Laporan Keuangan di Sekolah Menengah Atas Belin Puspa Sari, Zahruddin Hodsay, Hendri Gunawan

DOI: https://doi.org/10.31004/edukatif.v4i1.1993

Standar Perhitungan Rasio Modal Sendiri Terhadap Total Asset

\begin{tabular}{cccc}
\hline Rasio Modal (\%) & Nilai & Bobot (\%) & Skor \\
\hline $0 \leq \mathrm{X}<20$ & 25 & 6 & 1,50 \\
\hline $20 \leq \mathrm{X}<40$ & 50 & 6 & 3,00 \\
\hline $40 \leq \mathrm{X}<60$ & 100 & 6 & 6,00 \\
\hline $60 \leq \mathrm{X}<80$ & 50 & 6 & 3,00 \\
\hline $80 \leq \mathrm{X} \leq 100$ & 25 & 6 & 1,50 \\
\hline
\end{tabular}

Nilai-nilai yang dinyatakan pada tabel 2 dan 3 di atas, selanjutnya disubsitusikan sehingga diperoleh tabel berikut:

Tabel 4

Penskoran Rasio Modal Sendiri Terhadap Total Asset Tahun 2018-2020

\begin{tabular}{ccccccc}
\hline Rasio & Tahun & Rasio (\%) & Nilai (a) & Bobot (\%) (b) & Skor (a)*(b) \\
\hline Rasio modal sendiri & 2018 & $45,35 \%$ & 100 & 6 & 6 \\
\cline { 2 - 7 } terhadap Total asset & 2019 & $51,88 \%$ & 100 & 6 & 6 \\
\cline { 2 - 7 } & 2020 & $49,10 \%$ & 100 & 6 & 6 \\
\hline
\end{tabular}

Berdasarkan perhitungan rasio modal sendiri terhadap total asset, pada tahun 2018 sebesar 45,35\%, selanjutnya pada tahun 2019 terjadi peningkatan sebesar 6,53\%, dan pada tahun 2020 terjadi penurunan sebesar $2,78 \%$.

2. Rasio Kecukupan Modal

Rasio kecukupan modal sendiri merupakan perbandingan modal sendiri tertimbang dengan aktiva tertimbang menurut risiko adalah:

Tabel 5

Perhitungan Modal Sendiri Tertimbang Tahun 2018

\begin{tabular}{lccc}
\hline \multicolumn{1}{c}{ Komponen Modal } & Nilai & $\begin{array}{c}\text { Bobot } \\
\text { Pengakuan }\end{array}$ & $\begin{array}{c}\text { Modal } \\
\text { Tertimbang }\end{array}$ \\
\hline 1. Simpanan pokok & $\mathrm{Rp} 12.600 .000$ & $100 \%$ & $\mathrm{Rp} 12.600 .000$ \\
\hline 2. Simpanan wajib & $\mathrm{Rp} \mathrm{33.600.000}$ & $100 \%$ & $\mathrm{Rp} \mathrm{33.600.000}$ \\
\hline 3. Dana cadangan & $\mathrm{Rp} 3.765 .000$ & $100 \%$ & $\mathrm{Rp} 3.765 .000$ \\
\hline 4. SHU yang dibagikan & $\mathrm{Rp} 8.010 .400$ & $50 \%$ & $\mathrm{Rp} 4.005 .200$ \\
\hline Jumlah Modal Tertimbang & $\mathrm{Rp} \mathrm{57.975.400}$ & - & $\mathrm{Rp} \mathrm{53.970.200}$ \\
\hline
\end{tabular}

Perhitungan aktiva tertimbang pada Koperasi Sekolah di SMA Negeri 4 Palembang tahun 2018 dapat dilihat pada tabel berikut:

Tabel 6

Perhitungan Aktiva Tertimbang Menurut Risiko Tahun 2018

\begin{tabular}{ccccc}
\hline Komponen Aktiva & Nilai & $\begin{array}{c}\text { Bobot } \\
\text { Pengakuan }\end{array}$ & $\begin{array}{c}\text { Modal } \\
\text { Tertimbang }\end{array}$ \\
\hline 1. Kas & $\mathrm{Rp} 68.849 .400$ & $0 \%$ & $\mathrm{Rp},-$ \\
\hline 2. Persediaan barang dagang & $\mathrm{Rp} 10.260 .000$ & $100 \%$ & $\mathrm{Rp} 10.260 .000$ \\
\hline 3. Piutang & $\mathrm{Rp} 20.721 .000$ & $100 \%$ & $\mathrm{Rp} 20.721 .000$ \\
\hline 4. Perlengkapan & $\mathrm{Rp}$ & 7.000 .000 & $100 \%$ & $\mathrm{Rp} 7.000 .000$ \\
\hline 5. Peralatan & $\mathrm{Rp} 3.345 .000$ & $70 \%$ & $\mathrm{Rp} 2.341 .500$ \\
\hline Jumlah ATMR & $\mathrm{Rp} 110.175 .400$ & - & $\mathrm{Rp} 40.322 .500$ \\
\hline
\end{tabular}

Berdasarkan tabel 5 dan 6 di atas, diperoleh nilai yang selanjutnya disubsitusikan, sehingga diperoleh:

$$
\begin{aligned}
& =\frac{53.970 .200}{40.322 .500} \times 100 \% \\
& =133,85 \%
\end{aligned}
$$


1101 Analisis Pengelolaan Koperasi Sekolah Melalui Rasio Laporan Keuangan di Sekolah Menengah Atas Belin Puspa Sari, Zahruddin Hodsay, Hendri Gunawan

DOI: https://doi.org/10.31004/edukatif.v4i1.1993

Perhitungan yang sama untuk tahun 2019 dan 2020, sehingga hasil secara keseluruhan dapat dilihat pada tabel berikut:

\section{Tabel 7}

Rasio Kecukupan Modal Sendiri Tahun 2018-2020

\begin{tabular}{cccc}
\hline Tahun & Modal Tertimbang & ATMR & Rasio \\
\hline 2018 & Rp53.970.200 & Rp40.322.500 & $133,85 \%$ \\
\hline 2019 & Rp84.793.250 & Rp48.600.000 & $174,47 \%$ \\
\hline 2020 & Rp48.989.000 & Rp18.180.000 & $254,65 \%$ \\
\hline
\end{tabular}

Tabel di atas, selanjutnya diintepretasikan pada standar perhitungan rasio kecukupan modal sendiri pada tabel berikut:

Tabel 8

Standar Perhitungan Rasio Kecukupan Modal Sendiri

\begin{tabular}{cccc}
\hline Rasio Modal (\%) & Nilai & Bobot (\%) & Skor \\
\hline $\mathrm{X}<4$ & 0 & 3 & 0,00 \\
\hline $4 \leq \mathrm{X}<6$ & 50 & 3 & 1,50 \\
\hline $6 \leq \mathrm{X}<8$ & 75 & 3 & 2,25 \\
\hline$>8$ & 100 & 3 & 3,00 \\
\hline
\end{tabular}

Nilai-nilai pada tabel 7 dan 8 di atas, selanjutnya disubsitusikan sehingga diperoleh tabel berikut:

Tabel 9

Penskoran Rasio Kecukupan Modal Sendiri Tahun 2018-2020

\begin{tabular}{ccccccc}
\hline Rasio & Tahun & Rasio (\%) & Nilai (a) & Bobot (\%) (b) & Skor (a)*(b) \\
\hline Rasio kecukupan modal sendiri & 2018 & $133,85 \%$ & 100 & 3 & 3 \\
\cline { 2 - 7 } & 2019 & $174,47 \%$ & 100 & 3 & 3 \\
\cline { 2 - 6 } & 2020 & $254,65 \%$ & 100 & 3 & 3 \\
\hline
\end{tabular}

Berdasarkan perhitungan rasio kecukupan modal sendiri pada tahun 2018 sebesar 133,85\%, selanjutnya pada tahun 2019 terjadi peningkatan sebesar 40,62\%, dan pada tahun 2020 juga terjadi peningkatan sebesar $80,18 \%$

Efisiensi merupakan aspek penilaian yang bertujuan untuk menggambarkan sampai seberapa besar koperasi mampu memberikan pelayanan yang efisien kepada anggotanya dari penggunaan asset yang dimilikinya. Penilaian efisiensi didasarkan pada 3 (tiga) rasio, yaitu: rasio beban operasi anggota terhadap partisipasi bruto, rasio beban usaha terhadap SHU kotor dan rasio efisiensi pelayanan. Analisis ini dikarenakan tidak adanya beban operasi anggota. Jelasnya analisis ke-3 rasio diuraikan sebagai berikut:

1. Rasio beban operasi anggota terhadap partisipasi bruto

a. Tahun 2018

$$
\begin{aligned}
& =\frac{810.000}{9.424 .000} \times 100 \% \\
& =8,60 \%
\end{aligned}
$$

b. Tahun 2019

$$
\begin{aligned}
& =\frac{1.030 .000}{30.090 .000} \times 100 \% \\
& =3,42 \%
\end{aligned}
$$

c. Tahun 2020

$$
\begin{aligned}
& =\frac{680.000}{6.340 .000} \times 100 \% \\
& =10,73 \%
\end{aligned}
$$


1102 Analisis Pengelolaan Koperasi Sekolah Melalui Rasio Laporan Keuangan di Sekolah Menengah Atas Belin Puspa Sari, Zahruddin Hodsay, Hendri Gunawan

DOI: https://doi.org/10.31004/edukatif.v4i1.1993

Hasil perhitungan rasio beban operasi anggota terhadap partisipasi bruto Koperasi di SMA Negeri 4 Palembang dapat dilihat pada tabel berikut.

Tabel 10

Rasio Beban Operasi Anggota terhadap Partisipasi Bruto tahun 2018-2020

\begin{tabular}{cccc}
\hline Tahun & Beban Operasi Anggota & SHU Kotor & Rasio \\
\hline 2018 & $R p ~ 810.000$ & $R p 9.424 .000$ & $8,60 \%$ \\
\hline 2019 & $R p 1.030 .000$ & $R p 30.090 .000$ & $3,42 \%$ \\
\hline 2020 & $R p 680.000$ & $R p 6.340 .000$ & $10,73 \%$ \\
\hline
\end{tabular}

Tabel 10 di atas, selanjutnya diintepretasikan pada standar perhitungan rasio beban operasi anggota terhadap partisipasi bruto pada tabel berikut:

Tabel 11

Standar Perhitungan Rasio Beban Operasi Anggota terhadap Partisipasi Bruto Tahun 2018-2020

\begin{tabular}{cccc}
\hline $\begin{array}{c}\text { Rasio Beban Operasi Anggota terhadap } \\
\text { Partisipasi Bruto (\%) }\end{array}$ & Nilai & $\begin{array}{c}\text { Bobot } \\
(\boldsymbol{\%})\end{array}$ & Skor \\
\hline$\geq 100$ & 0 & 4 & 1 \\
\hline $95 \leq X<100$ & 50 & 4 & 2 \\
\hline $90 \leq X<95$ & 75 & 4 & 3 \\
\hline$<90$ & 100 & 4 & 4 \\
\hline
\end{tabular}

Nilai-nilai yang tertera pada tabel 10 dan 11 di atas, selanjutnya disubsitusikan sehingga diperoleh tabel berikut:

Tabel 12

Penskoran Rasio Beban Operasi Anggota terhadap Partisipasi Bruto Tahun 2018-2020

\begin{tabular}{cccccc}
\hline Rasio & Tahun & Rasio & Nilai (a) & $\begin{array}{c}\text { Bobot } \\
(\boldsymbol{\%})(\mathbf{b})\end{array}$ & $\begin{array}{c}\text { Skor } \\
(\mathbf{a}) *(\mathbf{b})\end{array}$ \\
\hline $\begin{array}{c}\text { Rasio Beban Operasi Anggota } \\
\text { terhadap Partisipasi Bruto }\end{array}$ & 2018 & $8,60 \%$ & 100 & 4 & 4,00 \\
\cline { 2 - 6 } & 2019 & $3,42 \%$ & 100 & 4 & 4,00 \\
\cline { 2 - 6 } & 2020 & $10,73 \%$ & 100 & 4 & 4,00 \\
\hline
\end{tabular}

Berdasarkan perhitungan rasio beban operasi anggota terhadap partisipasi bruto pada tahun 2018 sebesar 8,60\%; pada tahun 2019 terjadi penurunan sebesar 5,18\%; dan pada trahun 2020 terjadi peningkatan sebesar $7,31 \%$.

2. Rasio beban usaha terhadap SHU kotor

a. Tahun 2018

$$
\begin{aligned}
& =\frac{250.000}{9.424 .000} \times 100 \% \\
& =2,65 \%
\end{aligned}
$$

b. Tahun 2019

$$
\begin{aligned}
& =\frac{400.000}{30.090 .000} \times 100 \% \\
& =1,33 \%
\end{aligned}
$$

c. Tahun 2020

$$
\begin{aligned}
& =\frac{200.000}{6.340 .000} \times 100 \% \\
& =3,15 \%
\end{aligned}
$$

Hasil perhitungan rasio beban usaha terhadap SHU kotor Koperasi Sekolah di SMA Negeri 4 Palembang dapat dilihat pada tabel berikut: 
1103 Analisis Pengelolaan Koperasi Sekolah Melalui Rasio Laporan Keuangan di Sekolah Menengah Atas Belin Puspa Sari, Zahruddin Hodsay, Hendri Gunawan

DOI: https://doi.org/10.31004/edukatif.v4i1.1993

Tabel 13

Rasio Beban Usaha terhadap SHU Kotor tahun 2018-2020

\begin{tabular}{cccc}
\hline Tahun & Beban Usaha & SHU Kotor & Rasio \\
\hline 2018 & Rp250.000 & $\operatorname{Rp~} 9.424 .000$ & $2,65 \%$ \\
\hline 2019 & Rp400.000 & $\operatorname{Rp} 30.090 .000$ & $1,33 \%$ \\
\hline 2020 & Rp200.000 & $\operatorname{Rp~} 6.340 .000$ & $3,15 \%$ \\
\hline
\end{tabular}

Tabel 13 di atas, selanjutnya diintepretasikan pada standar perhitungan rasio beban usaha terhadap SHU kotor koperasi pada tabel berikut:

Tabel 14

Standar Perhitungan Rasio Beban Usaha terhadap SHU Kotor Tahun 2018-2020

\begin{tabular}{cccc}
\hline $\begin{array}{c}\text { Rasio Beban Usaha terhadap } \\
\text { SHU Kotor }(\boldsymbol{\%})\end{array}$ & Nilai & $\begin{array}{c}\text { Bobot } \\
(\mathbf{\%})\end{array}$ & Skor \\
\hline$>80$ & 25 & 4 & 1 \\
\hline $60<X \leq 80$ & 50 & 4 & 2 \\
\hline $40<X \leq 60$ & 75 & 4 & 3 \\
\hline $0<\mathrm{x} \leq 40$ & 100 & 4 & 4 \\
\hline
\end{tabular}

Nilai-nilai yang diperoleh pada tabel 13 dan 14 di atas, selanjutnya disubsitusikan pada tabel di bawah ini.

Tabel 15

Penskoran Rasio Beban Usaha terhadap SHU Kotor Tahun 2018-200

\begin{tabular}{cccccc}
\hline Rasio & Tahun & Rasio & Nilai (a) & Bobot (\%) (b) & Skor (a)*(b) \\
\hline Rasio Beban Usaha & 2018 & $2,65 \%$ & 100 & 4 & 4,00 \\
\cline { 2 - 6 } terhadap SHU Kotor & 2019 & $1,33 \%$ & 100 & 4 & 4,00 \\
\cline { 2 - 6 } & 2020 & $3,15 \%$ & 100 & 4 & 4,00 \\
\hline
\end{tabular}

Berdasarkan perhitungan rasio beban usaha terhadap SHU Kotor pada tahun 2018 sebesar 2,65\%; pada tahun 2019 terjadi penurunan sebesar 1,32\%; dan pada trahun 2020 terjadi peningkatan sebesar 1,82\%

3. Rasio efisiensi pelayanan

a. Tahun 2018

$$
=\frac{560.000}{20.721 .000} \times 100 \%
$$

$=2,70 \%$

b. Tahun 2019

$$
\begin{aligned}
& =\frac{630.000}{14.800 .000} \times 100 \% \\
& =4,26 \%
\end{aligned}
$$

c. Tahun 2020

$=\frac{480.000}{15.500 .000} \times 100 \%$

$=3,10 \%$

Hasil perhitungan rasio efisiensi pelayanan Koperasi Sekolah di SMA Negeri 4 Palembang dapat dilihat pada tabel berikut:

Tabel 16

Rasio Efisiensi Pelayanan Koperasi Sehati SMAN 4 Palembang Tahun 2018-2020

\begin{tabular}{cccc}
\hline Tahun & Biaya Karyawan & Volume Pinjaman & Rasio \\
\hline 2018 & Rp560.000 & Rp20.721.000 & $2,70 \%$ \\
\hline 2019 & Rp630.000 & Rp14.800.000 & $4,26 \%$ \\
\hline
\end{tabular}


1104 Analisis Pengelolaan Koperasi Sekolah Melalui Rasio Laporan Keuangan di Sekolah Menengah Atas Belin Puspa Sari, Zahruddin Hodsay, Hendri Gunawan

DOI: https://doi.org/10.31004/edukatif.v4i1.1993

\begin{tabular}{llll}
2020 & $\mathrm{Rp} 480.000$ & $\mathrm{Rp} 15.500 .000$ & $3,10 \%$ \\
\hline
\end{tabular}

Tabel 16 di atas, selanjutnya diintepretasikan pada standar perhitungan rasio efisiensi pelayanan pada tabel berikut:

Tabel 17

Standar Perhitungan Rasio Efisiensi Pelayanan

\begin{tabular}{cccc}
\hline Rasio Efisiensi Pelayana & Nilai & Bobot $(\%)$ & Skor \\
\hline$<5$ & 100 & 2 & 2,0 \\
\hline $5<\mathrm{x}<10$ & 75 & 2 & 1,5 \\
\hline $10<\mathrm{x}<15$ & 50 & 2 & 1,0 \\
\hline$>15$ & 0 & 2 & 0,0
\end{tabular}

Nilai-nilai yang tertera pada tabel 16 dan 17 di atas, selanjutnya disubsitusikan sehingga diperoleh tabel berikut:

Tabel 18

Penskoran Rasio Efisiensi Pelayanan Tahun 2018-2020

\begin{tabular}{cccccc}
\hline Rasio & Tahun & Rasio (\%) & Nilai (a) & Bobot (\%) (b) & Skor (a)*(b) \\
\hline Efisiensi pelayanan & 2018 & $2,70 \%$ & 100 & 2 & 2 \\
\cline { 2 - 7 } & 2019 & $4,26 \%$ & 100 & 2 & 2 \\
\cline { 2 - 6 } & 2020 & $3,10 \%$ & 100 & 2 & 2 \\
\hline
\end{tabular}

Berdasarkan perhitungan rasio efisiensi pelayanan pada tahun 2018 sebesar 2,70\%, selanjutnya pada tahun 2019 terjadi peningkatan sebesar 1,56\%, dan pada tahun 2020 terjadi penurunan sebesar 1,16\% .

Penilaian terhadap kemandirian dan pertumbuhan didasarkan pada 3 (tiga) rasio, yaitu rentabilitas asset, rentabilitas modal sendiri, dan kemandirian operasional. Jelasnya kemandirian dan pertumbuhan dianalisis sebagai berikut:

1. Rasio rentabilitas asset

a. Tahun 2018

$$
\begin{aligned}
& =\frac{9.424 .000}{110.175 .400} \times 100 \% \\
& =8,55 \%
\end{aligned}
$$

b. Tahun 2019

$$
\begin{aligned}
& =\frac{30.090 .000}{138.790 .500} \times 100 \% \\
& =21,68 \%
\end{aligned}
$$

c. Tahun 2020

$$
\begin{aligned}
& =\frac{6.340 .000}{88.794 .000} \times 100 \% \\
& =7,14 \%
\end{aligned}
$$
berikut:

Hasil perhitungan rasio rentabilitas asset Koperasi di SMA Negeri 4 Palembang dapat dilihat pada tabel

Tabel 19

Hasil Perhitungan Rasio Rentabilitas Asset Tahun 2018-2020

\begin{tabular}{cccc}
\hline Tahun & SHU Sebelum Pajak & Total Asset & Rasio \\
\hline 2018 & $\mathrm{Rp} 9.424 .000$ & $\mathrm{Rp} 110.175 .400$ & $8,55 \%$ \\
\hline 2019 & $\mathrm{Rp} 30.090 .000$ & $\mathrm{Rp} 138.790 .500$ & $21,68 \%$ \\
\hline 2020 & $\mathrm{Rp} 6.340 .000$ & $\mathrm{Rp} 88.794 .000$ & $7,14 \%$ \\
\hline
\end{tabular}


1105 Analisis Pengelolaan Koperasi Sekolah Melalui Rasio Laporan Keuangan di Sekolah Menengah Atas Belin Puspa Sari, Zahruddin Hodsay, Hendri Gunawan

DOI: https://doi.org/10.31004/edukatif.v4i1.1993

Tabel 19 di atas, selanjutnya diintepretasikan pada standar perhitungan rasio rentabilitas asset koperasi pada tabel berikut:

Tabel 20

Standar Perhitungan Skor untuk Rasio Rentabilitas Asset

\begin{tabular}{cccc}
\hline Rasio Rentabilitas Asset (\%) & Nilai & Bobot (\%) & Skor \\
\hline$<5$ & 25 & 3 & 0,75 \\
\hline $5 \leq X<7,5$ & 50 & 3 & 1,50 \\
\hline $7,5 \leq X<10$ & 75 & 3 & 2,25 \\
\hline$\geq 20$ & 100 & 3 & 3,00 \\
\hline
\end{tabular}

Nilai-nilai yang terterap pada tabel 19 dan 20 di atas, selanjutnya disubsitusikan sehingga diperoleh tabel berikut:

Tabel 21

Penskoran Rentabilitas Asset Tahun 2018-2020

\begin{tabular}{cccccc}
\hline Rasio & Tahun & $\begin{array}{c}\text { Rasio } \\
(\mathbf{\%})\end{array}$ & $\begin{array}{c}\text { Nilai } \\
(\mathbf{a})\end{array}$ & $\begin{array}{c}\text { Bobot }(\%) \\
(\mathbf{b})\end{array}$ & $\begin{array}{c}\text { Skor } \\
(\mathbf{a}) *(\mathbf{b})\end{array}$ \\
\hline Rentabilitas & 2018 & $8,55 \%$ & 75 & 3 & 2,25 \\
\cline { 2 - 6 } Asset & 2019 & $21,68 \%$ & 100 & 3 & 3,00 \\
\cline { 2 - 6 } & 2020 & $7,14 \%$ & 50 & 3 & 1,50 \\
\hline
\end{tabular}

Berdasarkan perhitungan rasio rentabilitas asset Koperasi tahun 2018 sebesar 8,55\%: pada tahun 2019 terjadi peningkatan sebesar 13,13\%: dan pada tahun 2020 terjadi penurunan sebesar 14,54\%.

2. Rasio rentabilitas modal sendiri

a. Tahun 2018

$$
\begin{aligned}
& =\frac{8 \cdot 010.400}{49.965 .000} \times 100 \% \\
& =16,03 \%
\end{aligned}
$$

b. Tahun 2019

$$
\begin{aligned}
& =\frac{25.576 .500}{72.005 .000} \times 100 \% \\
& =35,52 \%
\end{aligned}
$$

c. Tahun 2020

$$
\begin{aligned}
& =\frac{5.389 .000}{43.600 .000} \times 100 \% \\
& =12,36 \%
\end{aligned}
$$

Hasil perhitungan rasio rentabilitas modal sendiri pada Koperasi SMA Negeri 4 Palembang dapat dilihat pada tabel berikut:

\section{Tabel 22}

Hasil Perhitungan Rasio Rentabilitas Modal Sendiri Tahun 2018-2020

\begin{tabular}{ccrr}
\hline Tahun & SHU Bagian Anggota & Modal Sendiri & Rasio \\
\hline 2018 & Rp 8.010 .400 & Rp49.965.000 & $16,03 \%$ \\
\hline 2019 & Rp25.576.500 & Rp72.005.000 & $35,52 \%$ \\
\hline 2020 & Rp 5.389 .000 & $R p 43.600 .000$ & $12,36 \%$ \\
\hline
\end{tabular}

Tabel 22 di atas, selanjutnya diintepretasikan pada standar perhitungan rasio rentabilitas modal sendiri pada tabel berikut: 
1106 Analisis Pengelolaan Koperasi Sekolah Melalui Rasio Laporan Keuangan di Sekolah Menengah Atas Belin Puspa Sari, Zahruddin Hodsay, Hendri Gunawan

DOI: https://doi.org/10.31004/edukatif.v4i1.1993

Tabel 23

Standar Perhitungan Skor untuk Rasio Rentabilitas Modal Sendiri

\begin{tabular}{cccc}
\hline $\begin{array}{c}\text { Rasio Rentabilitas Modal Sendiri } \\
(\mathbf{\%})\end{array}$ & Nilai & $\begin{array}{c}\text { Bobot } \\
(\boldsymbol{\%})\end{array}$ & Skor \\
\hline$<3$ & 25 & 3 & 0,75 \\
\hline $3 \leq X<4$ & 50 & 3 & 1,50 \\
\hline $4 \leq X<5$ & 75 & 3 & 2,25 \\
\hline$\geq 5$ & 100 & 3 & 3,00 \\
\hline
\end{tabular}

Nilai-nilai yang terteta pada tabel 22 dan 23 di atas, selanjutnya disubsitusikan sehingga diperoleh tabel berikut:

Tabel 24

Penskoran Rentabilitas Modal Sendiri Tahun 2018-2020

\begin{tabular}{cccccc}
\hline Rasio & Tahun & $\begin{array}{c}\text { Rasio } \\
(\boldsymbol{\%})\end{array}$ & $\begin{array}{c}\text { Nilai } \\
(\mathbf{a})\end{array}$ & $\begin{array}{c}\text { Bobot } \\
(\boldsymbol{\%}) \mathbf{( b )}\end{array}$ & $\begin{array}{c}\text { Skor } \\
(\mathbf{a}) *(\mathbf{b})\end{array}$ \\
\hline Rentabilitas & 2018 & $16,03 \%$ & 100 & 3 & 3,0 \\
\cline { 2 - 6 } Modal Sendiri & 2019 & $35,52 \%$ & 100 & 3 & 3,0 \\
\cline { 2 - 6 } & 2020 & $12,36 \%$ & 100 & 3 & 3,0 \\
\hline
\end{tabular}

Berdasarkan perhitungan rasio rentabilitas modal sendiri pada tahun 2018 sebesar 16,03\%: pada tahun 2019 terjadi peningkatan 15,49\%: dan pada tahun 2020 terjadi penurunan $23,16 \%$.

3. Rasio kemandirian operasional

a. Tahun 2018

$$
\begin{aligned}
& =\frac{8.010 .400}{760.000+50.000} \times 100 \% \\
& =\frac{8.010 .400}{810.000} \times 100 \% \\
& =988,94 \%
\end{aligned}
$$

b. Tahun 2019

$$
=\frac{25.576 .500}{930.000+100.000} \times 100 \%
$$$$
=\frac{25.576 .500}{1.030 .000} \times 100 \%
$$

$=2483,16 \%$

c. Tahun 2020

$$
\begin{aligned}
& =\frac{5.389 .000}{630.000+50.000} \times 100 \% \\
& =\frac{5.389 .000}{680.000} \times 100 \% \\
& =792,50 \%
\end{aligned}
$$

Hasil perhitungan rasio kemandirian operasional Koperasi di SMA Negeri 4 Palembang dapat dilihat pada tabel berikut:

Tabel 25

Hasil Perhitungan Rasio Kemandirian Operasional Tahun 2018-2020

\begin{tabular}{crcc}
\hline Tahun & Partisipasi Netto & Beban Usaha + Beban Perkoperasian & Rasio \\
\hline 2018 & $\mathrm{Rp} 8.010 .400$ & $\mathrm{Rp} 810.000$ & $988,94 \%$ \\
\hline 2019 & $\mathrm{Rp} 25.576 .500$ & $\mathrm{Rp} 1.030 .000$ & $2483,16 \%$ \\
\hline 2020 & $\mathrm{Rp} 5.389 .000$ & $\mathrm{Rp} 680.000$ & $792,50 \%$ \\
\hline
\end{tabular}


1107 Analisis Pengelolaan Koperasi Sekolah Melalui Rasio Laporan Keuangan di Sekolah Menengah Atas Belin Puspa Sari, Zahruddin Hodsay, Hendri Gunawan

DOI: https://doi.org/10.31004/edukatif.v4i1.1993

Tabel 25 di atas, selanjutnya diintepretasikan pada standar perhitungan rasio kemandirian operasional pada table berikut:

Tabel 26

Standar Perhitungan Skor untuk Rasio Kemandirian Operasional

\begin{tabular}{ccccc}
\hline $\begin{array}{c}\text { Rasio Kemandirian Operasional } \\
(\boldsymbol{\%})\end{array}$ & Nilai & $\begin{array}{c}\text { Bobot } \\
(\boldsymbol{\%})\end{array}$ & Skor \\
\hline 100 & 0 & 4 & 0 \\
\hline$>100$ & 100 & 4 & 4
\end{tabular}

Nilai-nilai yang ditunjukkan pada tabel 25 dan 26 di atas, selanjutnya disubsitusikan sehingga diperoleh tabel berikut:

Tabel 27

Penskoran Kemandirian Operasional Tahun 2018-2020

\begin{tabular}{cccccc}
\hline \multirow{2}{*}{ Rasio } & Tahun & Rasio (\%) & $\begin{array}{c}\text { Nilai } \\
\text { (a) }\end{array}$ & $\begin{array}{c}\text { Bobot (\%) } \\
\text { (b) }\end{array}$ & $\begin{array}{c}\text { Skor } \\
(\mathbf{a}) *(\mathbf{b})\end{array}$ \\
\hline $\begin{array}{c}\text { Kemandirian } \\
\text { Operasional }\end{array}$ & 2018 & $988,94 \%$ & 100 & 4 & 4,0 \\
\cline { 2 - 6 } & 2019 & $2483,16 \%$ & 100 & 4 & 4,0 \\
\cline { 2 - 6 } & 2020 & $792,50 \%$ & 100 & 4 & 4,0 \\
\hline
\end{tabular}

Berdasarkan perhitungan rasio kemandirian operasional pada Koperasi Sekolah di SMA Negeri 4 Palembang pada tahun 2018 sebesar 988,94\%: pada tahun 2019 terjadi peningkatan sebesar 1494,22\%: dan pada tahun 2020 terjadi penurunan sebesar 1690,66\%.

Dari tiga aspek yang dinilai dalam penilaian kesehatan koperasi yaitu aspek permodalan, efisiensi serta kemandirian dan pertumbuhan selanjutnya dari skor masing-masing apek kemudian diakumulasikan untuk menentukan kriteria kesehatan koperasi. Penilaian skor untuk menetapkan kesehatan Koperasi Sekolah akan diintepretasikan pada tabel berikut:

Tabel 28

Rangkuman Penilaian Kesehatan Koperasi di SMA Negeri 4 Palembang Tahun 2018-2020

\begin{tabular}{|c|c|c|c|c|c|}
\hline \multirow{2}{*}{ No } & \multirow{2}{*}{ Aspek yang Dinilai } & \multicolumn{3}{|c|}{ Tahun } & \multirow{2}{*}{$\begin{array}{l}\text { Rata- } \\
\text { Rata }\end{array}$} \\
\hline & & 2018 & 2019 & 2020 & \\
\hline \multirow[t]{3}{*}{1} & Permodalan & & & & \\
\hline & Rasio modal sendiri & 6,00 & 6,00 & 6,00 & 6,00 \\
\hline & Rasio kecukupan modal & 3,00 & 3,00 & 3,00 & 3,00 \\
\hline \multirow[t]{4}{*}{2} & Efisiensi & & & & \\
\hline & Rasio beban operasi anggota terhadap partisipasi bruto & 4,00 & 4,00 & 4,00 & 4,00 \\
\hline & Rasio beban terhadap SHU kotor & 4,00 & 4,00 & 4,00 & 4,00 \\
\hline & Rasio efisiensi pelayanan & 2,00 & 2,00 & 2,00 & 2,00 \\
\hline \multirow[t]{6}{*}{3} & Kemandirian dan pertumbuhan & & & & \\
\hline & Rentabilitas asset & 2,25 & 3,00 & 1,50 & 2,25 \\
\hline & Rentabilitas modal sendiri & 3,00 & 3,00 & 3,00 & 3,00 \\
\hline & Kemandirian operasional & 4,00 & 4,00 & 4,00 & 4,00 \\
\hline & Skor Akhir & 28,25 & 29,00 & 27,5 & 28,25 \\
\hline & Predikat & Sehat & Sehat & Sehat & Sehat \\
\hline
\end{tabular}

Koperasi adalah suatu badan usaha bersama yang bergerak dalam bidang perekonomian, beranggotakan mereka yang umumnya berekonomi lemah yang bergabung secara sukarela dan atas dasar persamaan hak, berkewajiban melakukan suatu usaha yang bertujuan untuk memenuhi kebutuhan-kebutuhan para anggotanya. Hal ini sebagaimana dikemukakan (Sumantri, 2017), bahwa koperasi adalah organisasi bisnis yang dimiliki dan dioperasikan oleh orang-seorang demi kepentingan bersama. Koperasi yang diadakan di sekolah berupa unit simpan pinjam dan penyediaan kebutuhan sekolah. Menurut (Itang, 2016), koperasi simpan pinjam merupakan koperasi yang anggota-anggotanya terdiri dari setiap orang yang mempunyai kepentingan 
1108 Analisis Pengelolaan Koperasi Sekolah Melalui Rasio Laporan Keuangan di Sekolah Menengah Atas Belin Puspa Sari, Zahruddin Hodsay, Hendri Gunawan

DOI: https://doi.org/10.31004/edukatif.v4i1.1993

langsung dalam lapangan simpan pinjam. Lapangan usaha simpan pinjam menggiatkan anggotanya untuk menyimpan escara teratur dan memberi pinjaman kepada anggotanya untuk tujuan yang bermanfaat dengan pemungutan uang-jasa serendah mungkin. Sedangkan menurut (Swasono, 2015), koperasi adalah suatu lembaga sosial-ekonomi untuk menolong diri sendiri secara bersama-sama. Upaya ini dapat tumbuh dari dalam masyarakat sendiri berkat munculnya kesadaran bersama untuk pemberdayaan-diri (self-empowering), namun dapat pula ditumbuhkan dari luar masyarakat sebagai pemberdayaan oleh agents of deployment, baik oleh pemerintah, elit masyarakat maupun oleh organisasi-organisasi kemasyarakatan, LSM dan lain-lain. Koperasi pada SMA Negeri 4 Palembang berdasarkan prinsip gerakan ekonomi kebersamaan yang berdasarkan asas kekeluargaan. Pengelolaan koperasi pada umumnya ditujukan untuk memberikan pelayanan kepada anggota. Kegiatan dalam menghimpun dana dari untuk anggota sehingga diperolehnya modal bersama. Selain itu, unit usaha yang dijalankan adalah koperasi simpan pinjam. Menurut (Subagyo, 2017), koperasi simpan pinjam merupakan lembaga keuangan atau unit usaha simpan pinjam yang telah berbadan hukum yang melakukan kegiatan usahanya dengan menghimpun dana dari anggota dalam bentuk simpanan, dan menyalurkan kepada anggotanya dalam bentuk pinjaman atau bentuk lainnya dengan tujuan untuk meningkatkan kesejahteraan anggotanya, melindungi dana masyarakat, dan mendorong tercapainya tujuan anggota. Koperasi simpan pinjam tentunya memberikan beberapa manfaat, sebagaimana pendapat (Muljono, 2014), yaitu memberi kemudahan bagi anggota untuk memperoleh modal usaha, memberi keuntungan kepada anggota melalui Sisa Hasil Usaha (SHU), mengembangkan usaha anggota koperasi, dan meniadakan praktek renternir.

Permodalan pada Koperasi Sekolah di SMA Negeri 4 Palembang dianalisis dengan cara membandingkan rasio modal sendiri terhadap total asset. Hasil analisis didapat rasio permodalan tertinggi pada tahun 2019 sebesar 54,68\%, berikutnya pada tahun 2020 sebesar 52,14\%, dan rasio terendah pada tahun 2018 sebesar 50,07\%. Hal ini menunjukkan bahwa rasio permodalan mengalami fluktuasi. Berarti modal sendiri yang dimiliki Koperasi Sehati SMA Negeri 4 Palembang dalam kondisi yang tidak stabil. Sedangkan dari analisis rasio kecukupan modal sendiri pada Koperasi Sekolah di SMA Negeri 4 Palembang tertinggi pada tahun 2020 sebesar 254,65\%, berikutnya pada tahun 2019 sebesar 174,47\%, dan rasio terendah pada tahun 2018 sebesar 133,85\%. Hal ini menunjukkan trend peningkatan dari tahun 2018-2019. Dilihat tingkat kesehatan koperasi, dari rasio modal sendiri terhadap total asset dan kecukupan modal sendiri dalam predikat sehat sehingga dapat mendukung kegiatan operasionalnya.

Penilaian lainnya pada rasio efisiensi, yaitu kemampuan koperasi dalam memberikan pelayanan yang efisien kepada anggotanya dari penggunaan asset yang dimilikinya. Rasio beban operasi anggota terhadap partisipasi bruto pada Koperasi Sekolah di SMA Negeri 4 Palembang pada tahun 2020 sebesar 10,73\%, berikutnya pada tahun 2018 sebesar 8,60\%, dan rasio terendah pada tahun 2019 sebesar 3,42\%. Sedangkan rasio beban usaha terhadap SHU kotor tertinggi pada tahun 2020 sebesar 3,15\%, berikutnya pada tahun 2018 sebesar 2,65\%, dan rasio terendah pada tahun 2019 sebesar 1,33\%. Menurut (Toman Sony Tambunan, 2019), pembagian Sisa Hasil Usaha (SHU) koperasi setelah disisihkan untuk dana cadangan diberikan kepada anggota sebanding dengan jasa usaha anggota, selain itu juga digunakan untuk keperluan pendidikan perkoperasian dan keperluan lainnya sesuai dengan ketetapan dalam Anggaran Dasar. Dengan demikian, maka Sisa Hasil Usaha (SHU) merupakan pendapatan yang diperoleh koperasi setelah dikurangi dengan pengeluaran dan beban-beban koperasi yang kemudian disisihan untuk dana cadangan, dibagikan kepada anggota koperasi sesuai dengan besarnya jasa anggota, dan keperluan lainnya sesuai dalam Anggaran Dasar. Demikian juga hasil analisis rasio efisiensi pelayanan, diperoleh rasio tertinggi pada tahun 2019 sebesar $4,26 \%$, berikutnya pada tahun 2020 sebesar $3,10 \%$, dan rasio terendah pada tahun 2018 sebesar $2,70 \%$. Hal ini menunjukkan bahwa tingkat efisiensi koperasi bersifat fluktuasi. Namun demikian, dilihat dari tingkat kesehatan koperasi pada rasio efisiensi dalam kondisi yang sehat. 
1109 Analisis Pengelolaan Koperasi Sekolah Melalui Rasio Laporan Keuangan di Sekolah Menengah Atas Belin Puspa Sari, Zahruddin Hodsay, Hendri Gunawan

DOI: https://doi.org/10.31004/edukatif.v4i1.1993

Dilihat dari perhitungan kemandirian dan pertumbuhan, diperoleh rasio rentabilitas asset koperasi diperoleh rasio tertinggi pada tahun 2019 sebesar 21,68\%, berikutnya pada tahun 2018 sebesar 8,55\%, dan rasio terendah pada tahun 2020 sebesar 7,14\%. Rasio berikutnya adalah rasio rentabilitas modal sendiri, dimana rasio tertinggi pada tahun 2019 sebesar 35,52\%, berikutnya pada tahun 2018 sebesar 16,03\%, dan rasio terendah pada tahun 2020 sebesar 12,36\%. Sedangkan hasil analisis rasio kemandirian operasional diperoleh rasio tertinggi pada tahun 2019 sebesar 2483,16\%, berikutnya pada tahun 2018 sebesar 988,94\%, dan rasio terendah pada tahun 2020 sebesar 792,50\%. Sedangkan rasio kemandirian dan pertumbuhan juga mengalami fluktuasi. Hal ini menunjukkan bahwa Koperasi Sekolah di SMA Negeri 4 Palembang mampu menggunakan aktiva dan modal untuk menghasilkan keuntungan secara efisien pada tahun 2019. Selain itu juga, dilihat dari tingkat kesehatan koperasi pada rasio kemandirian dan pertumbuhan pada 3 (tiga) tahun berturut-turut dari tahun 2018-2020 mencapai predikat sehat.

Keterbatasan yang peneliti temukan dalam penelitian ini diantaranya penerapan homeschooling (belajar di rumah) secara daring, sehingga aktivitas di sekolah terhenti atau tidak aktif. Hal ini menghambat peneliti untuk memperoleh data keuangan koperasi. Minimnya studi terdahulu yang mengkaji tingkat kesehatan koperasi sekolah, kurangnya referensi yang mendukung, data laporan keuangan koperasi sekolah tidak secara keseluruhan dapat menggambarkan tingkat kesehatan koperasi dikarenakan tidak tercantum atau dimuat dalam laporan keuangan.

Berdasarkan uraian di atas, dengan menganalisis tingkat kesehatan koperasi sekolah berdasarkan laporan keuangan dengan merujuk Peraturan Deputi Bidang Pengawasan Kementrian Koperasi dan Usaha Kecil dan Menengah No.06/Per/Dep.6/2016 tentang pedoman penilaian kesehatan koperasi simpan pinjam dan unit simpan pinjam koperasi berbeda dengan studi (Hodsasy, 2019), yaitu pemodalan koperasi dalam kategori cukup sehat, kualitas aktiva produktif dengan kategori kurang sehat, manajemen cukup sehat, efisiensi tergolong sehat, likuiditas dikategorikan kurang sehat, kemandirian dan pertumbuhan tergolong kurang sehat, dan jati diri koperasi dikategorikan kurang sehat. Tingkat kesehatan koperasi selama 3 tahun (2015-2017) secara keseluruhan dalam kategori pengawasan, sedangkan peneliti dalam kategori sehat. Dengan demikian, hasil penelitian yang telah diuraikan di atas terkait dengan tujuan penelitian telah tercapai yang ditunjukkan oleh hasil penelitian yaitu pengelolaan Koperasi Sekolah di SMA Negeri 4 Palembang melalui rasio laporan keuangan menunjukkan bahwa permodalan untuk dimensi rasio modal sendiri terhadap total asset dan rasio kecukupan modal sendiri, efisiensi untuk dimensi rasio beban operasi anggota terhadap partisipasi bruto dan rasio efisiensi pelayanan, serta kemandirian kemandirian dan pertumbuhan untuk dimensi rasio rentabilitas asset, rasio rentabilitas modal sendiri dan rasio kemandirian operasional pada Koperasi Sekolah di SMA Negeri 4 Palembang tahun 2018-2020 dalam kondisi sehat.

\section{KESIMPULAN}

Berdasarkan hasil penelitian dan pembahasan, dapat disimpulkan bahwa pengelolaan Koperasi Sekolah di SMA Negeri 4 Palembang melalui rasio laporan keuangan menunjukkan bahwa permodalan untuk dimensi rasio modal sendiri terhadap total asset dan rasio kecukupan modal sendiri, efisiensi untuk dimensi rasio beban operasi anggota terhadap partisipasi bruto dan rasio efisiensi pelayanan, serta kemandirian kemandirian dan pertumbuhan untuk dimensi rasio rentabilitas asset, rasio rentabilitas modal sendiri dan rasio kemandirian operasional pada Koperasi Sekolah di SMA Negeri 4 Palembang tahun 2018-2020 dalam kondisi sehat.

Berdasarkan hasil simpulan di atas, maka peneliti memberikan beberapa saran hendaknya dalam melaksanakan kegiatan usahanya dimasa mendatang Koperasi Sekolah di SMA Negeri 4 Palembang memang perlu selalu mengevaluasi kondisi keuangan guna mendukung pengambilan keputusan organisasi. 
1110 Analisis Pengelolaan Koperasi Sekolah Melalui Rasio Laporan Keuangan di Sekolah Menengah Atas Belin Puspa Sari, Zahruddin Hodsay, Hendri Gunawan

DOI: https://doi.org/10.31004/edukatif.v4i1.1993

\section{UCAPAN TERIMA KASIH}

Selesainya penulisan jurnal ini, penulis mengucapkan terima kasih kepada Bapak Zahrudin Hodsay, S.Pd.,M.M., dan Bapak Hendri Gunawan, S.Pd.,M.Pd. yang telah memberikan bimbingan dan arahan.

\section{DAFTAR PUSTAKA}

Apriati, Y. (2021). Pendidikan Sosial Budaya Berbasis Permainan Rakyat di Masyarakat Lahan Basah. Edukatif: Jurnal Ilmu Pendidikan, 3(6), 4971-4980.

Bangsawan, S. (2016). Manajemen Pemasaran Usaha Koperasi. CV Anugrah Utama Raharja.

Cahyani, H. D. (2021). Peningkatan Sikap Disiplin dan Kemampuan Berpikir Siswa dengan Penerapan Model Pembelajaran Problem Based Learning. Edukatif: Jurnal Ilmu Pendidikan, 3(3), 919-927. https://doi.org/https://doi.org/10.31004/edukatif.v3i3.472

Fahmi, I. (2015). Manajamen Kinerja Teori dan Apliasi. Alfabeta.

Harahap, S. S. (2015). Analisis Kritis atas Laporan Keuangan. Rajawali Press.

Hodsasy, Z. (2019). Analisis Rasio Laporan Keuangan Koperasi Pelajar di SMK Negeri 1 Palembang. Jurnal Neraca, 6(2), 114-125. https://doi.org/https://doi.org/10.36706/jp.v6i2.9986

Itang. (2016). Pemikiran Ekonomi Koperasi Mohammad Hatta: Relevansinya dengan Etika Ekonomi Islam. Laksita Indonesia.

Larasati, D. (2021). Analisis Kesehatan KUD Sumber Tani Mandiri Desa Sumber Harum Kabupaten Musi Banyuasin. Competetive Jurnal Akuntansi Dan Keuangan, 5(2), 1-13.

Muljono, J. (2014). Buku Pintar Strategi Bisnis Koperasi Simpan Pinjam (Andi Offse).

Peraturan Deputi Bidang Pengawasan Kementerian Koperasi dan Usaha Kecil dan Menengah No.06/Per/Dep.6/2016 tentang Pedoman Penilaian Kesehatan Koperasi Simpan Pinjam dan Unit Simpan Pinjam.

Santoso, I. R. (2021). Pemberdayaan Ekonomi Kerakyatan (Memberdayakan Sektol Diil melalui Koperasi Jasa Keuangan Syariah BMT). Bintang Pustaka Madani.

Subagyo, A. (2017). Pengawasan Koperasi di Indonesia. Mitra Wacana Media.

Sugiyono. (2019). Metode Penelitian Pendekatan (Kuantitatif, Kualitatif, Kombinasi, R\&D dan Penelitian Pendidikan. Alfabeta.

Sukidjo. (2016). Koperasi Sekolah Sebagai Wadah Pengembangan Karakter Siswa. Jurnal Economia, 12(2), $122-134$.

Sukmayadi. (2020). Koperasi Syariah dari Teori untuk Praktek. Alfabeta.

Sumantri, B. A. dan E. P. P. (2017). Manajemen Koperasi dan Usaha Mikro Kecil dan Menengah (UMKM): Perkembangan Teori dan Praktek. Universitas Nusantara PGRI Kediri.

Swasono. (2015). Indonesia dan Doktrin Kesejahteraan Sosial, Perkumpulan. Pra Karsa.

Toman Sony Tambunan, dan H. T. (2019). Manajemen Koperasi. Yrama Media.

Undang-Undang Dasar tahun 1945 Pasal 33.

Undang-Undang RI Nomor 17 Tahun 2012 tentang Perkoperasian Pasal 1. 